Çukurova Üniversitesi Mühendislik Mimarlık Fakültesi Dergisi, 32(3), ss. 217-225, Eylül 2017

Çukurova University Journal of the Faculty of Engineering and Architecture, 32(3), pp. 217-225, September 2017

\title{
Süs Bitkisi Toprağında Arıtma Çamuru Stabilizasyonu
}

\author{
Gülgün DEDE ${ }^{* 1}$ \\ ${ }^{1}$ Sakarya Üniversitesi, Mühendislik Fakültesi, Çevre Mühendisliği Bölümü, Sakarya
}

Geliş tarihi: 06.04.2017～Kabul tarihi: 25.09 .2017

\section{$\ddot{O} z$}

Günden güne artan miktarlarda oluşan arıtma çamurlarının çevreye zarar vermeyecek bir şekilde bertarafı önemli bir konu haline gelmiştir. Arıtma çamurlarının en ekonomik ve sürdürülebilirliği en yüksek bertaraf seçeneği ise tarımsal amaçlı olmaktadır. Son yıllarda ekonomik bir değere sahip olan süs bitkileri yetiştiriciliğinde yüksek üretim girdi maliyetlerinin azalmasına yardımcı olan arıtma çamuru kullanımı ile hem ülke ekonomisine katkı sağlanmakta, hem de çamurun bertarafi konusunda yeni bir alternatif saha oluşturulmaktadır. Bu amaç doğrultusunda süs bitkisi olarak değerlendirilen Yucca massengena, Areca lutescens, Chlorophytum comosum, Ficus elastica, Dieffenbachia maculata, Croton petra ve Sansevieria trifasciata türleri topraklarına 2 farklı dozda (\%25 ve \%50) ilave edilen evsel nitelikli arıtma çamurunda zamana bağl fekal indikatör mikroorganizma giderimi incelenmiş̧ir. E. coli en hassas mikroorganizma olarak belirlenmiş ve 5 haftalık periyotta büyük oranda giderilmiştir $(>\% 90)$. Elde edilen sonuçlar incelendiğinde, başlangıçta B sınıfı kategorisinde yer alan arıtma çamurunun deneme sonunda incelenen mikroorganizmalar bazında A sınıfı özelliği taşıdığı tespit edilmiştir.

Anahtar Kelimeler: Arıtma çamuru, Yetiştirme ortamı, Süs bitkisi, Fekal mikroorganizma

\section{Stabilization of Sewage Sludge in Ornamental Plant Soil}

\begin{abstract}
The harmless elimination of sewage sludge that occurs in increasing quantities day to day has become an important issue. The most economical and sustainable disposal option of the sewage sludge is agricultural usage. In recent years, the use of sewage sludge as growing media for ornamental plants has reduce the high production input costs with an economic value, that contributes the economy and creates a new alternative site for the disposal. For this purpose, the time-based inactivation of fecal indicator microorganisms was investigated for two different doses (25\% and 50\%) of sewage sludge in growing substrates of Yucca massengena, Areca lutescens, Chlorophytum comosum, Ficus elastica, Dieffenbachia maculata, Croton petra and Sansevieria trifasciata. E. coli has been identified as the most sensitive microorganism and has been largely eliminated in the 5-week period (>90\%). As a result, sewage sludge that initially Class B category have been Class A at the end of the experiments.
\end{abstract}

Keywords: Sewage sludge, Growing media, Ornamental plant, Fecal microorganism

"Sorumlu yazar (Corresponding author): Gülgün DEDE, gulgunk@sakarya.edu.tr 


\section{GíRiş}

Dünya genelinde artan nüfus ve şehirleşmeye paralel olarak arıtma sistemlerinden oluşan arıtma çamuru miktarı her geçen gün artmaktadır. Oluşan arıtma çamurlarının bu kısa süre içindeki artışları bunların bertaraflarında da ciddi problemlere yol açmaktadır. Özellikle düzenli depolama alanlarını hızla doldurmaları ve bu alanlarda yol açtıkları ciddi problemler nedeniyle son y1llardaki yasal düzenlemeler ile arıtma çamurlarının içerdikleri organik maddenin tümü giderilmeden düzenli depolama alanlarına gönderilmeleri birçok ülkede yasaklanmıştır [1]. Arıtma çamurlarının yakılarak bertaraf edilmesi ise, gerek maliyetinin yüksek olması gerekse yakma işlemi sırasında açığa çıkan zehirli gazların hava kirliliği problemi oluşturması ile düşük sürdürülebilirliğe sahip bir seçenek olmaktadır. Arıtma çamurlarının geri dönüşüm gerekliliği ve çevresel sınırlamalar ise bu atıkların gübre alternatifi olarak önerilmelerine neden olmuş bilhassa Dünya çapında süs bitkileri yetiştiriciliğinde yetiştirme ortamı olarak başarıyla kullanılmış, kompost yapımı ile de ticari boyut değeri artırılmıştır [2, 3]. Avrupa Birliği ülkelerindeki yaklaşım da arıtma çamurlarının gübre amaçlı tarımda değerlendirilmesi yönünde olup bunun sonucunda arıtma çamurlarının, İngiltere'de \%52, İspanya'da \%65, Fransa'da \%70 oranında tarımsal amaçlı kullanımları söz konusu olup Almanya'da bitki yetiştirmede yaygın şekilde kullanılmaktadır. Su Çevre Federasyonu tarafından özetlenen günümüz EPA verilerine göre de Amerika'da üretilen arıtma çamurlarının \%60'ından fazlası tarımsal amaçlı kullanılmaktadır [3].

Ülkemizde süs bitkisi yetiştiriciliğinde yetiştirme ortamı olarak çoğunlukla toprak ve torf kullanılmaktadır. Ancak bu materyallerin kullanılması hem tarım alanlarında bir çeşit erozyona sebep olmakta hem de yetiştirme ortamı olarak istenen özellikleri tek başına sağlayamadıklarından, bitkiler yeterli büyüme performansı gösterememektedir. Bununla birlikte sürdürülebilir tarım ve çevre bir arada düşünüldüğünde doğal toprak kullanımı uygun değildir. Diğer yandan doğal torf yatakları yenilenebilir kaynak olsa da kısıtlı olan yatakların oluşumunun uzun zaman alması ve kazıların çevre bütünlüğünü bozarak doğayı tahrip etmesi ve karbondioksit döngüsünü bozması gibi nedenlerle sürdürülebilir bir seçenek olmamaktadır. Ayrıca yerel torf kaynaklarının yetersizliği de tüketiciyi ithal torfa yönlendirmekte bu durum da maliyetleri arttırmaktadır [1,3].

Bununla birlikte süs bitkisi sektörünün sürdürülebilirliğinin ve kendi kendine yeterliliğinin sağlanması ile çevreye olan etkilerinin oradan kaldırılması için yerel materyal ve teknolojilerle desteklenmesi gereklidir. Bu sebeple içerdikleri yüksek konsantrasyonlardaki organik madde nedeniyle arıtma çamurlarının bertarafı için en uygun yöntemlerden biri ülkemizde de gelişmekte olan sektörlerden süs bitkisi yetiştiriciliğinde kullanılmalarıdır [1,4-6]. Bunun yanı sıra toprağın fiziksel ve kimyasal yapısını düzeltme özelliği, arıtma çamurunun organik gübreleme için alternatif bir kaynak olarak kullanılma olanağı da sunmaktadır $[7,8]$. Bu açıdan bakıldığında bu yöntem, önemli bir gider olan yetiştirme ortamı ve gübreleme maliyetlerinin düşürülmesini sağlamasının yanı sıra her geçen gün artan miktarlara ulaşarak çevresel bir sorun haline gelen arıtma çamurlarının bertarafinda ekolojik ve ekonomik bir çözüm niteliği de taşımaktadır.

Süs bitkilerinin üretiminde yavaş salınımlı gübre büyük öneme sahiptir. Yavaş salınımlı gübre özelliği taşıyan arıtma çamurlarının süs bitkisi yetiştiriciliğinde ticari gübrelerin yerine kullanılmaları pek çok çalışmada denenmiş ve ortak bulgu çamurların bitki yetiştirmede ekonomik bir değer taşıdığı hususunda hiçbir kuşkunun bulunmaması olmuştur [9]. Bilhassa arıtma çamurunun bitki besin değerinin ahır gübresi ve organik komposta benzer olduğu ve bitkilerin gelişimi için gerekli tüm elementleri içerdiği bildirilmiştir [9]. Ayrıca arıtma çamurlarının besin olarak tüketilen ürünlerin yerine süs bitkisi yetiştiriciliğinde kullanılması psikolojik kabul edilebilirliği de sağlamaktadır $[1,10]$. 
Bunun yanı sıra ağır metal kapsamı ve sentetik organik kimyasallar bakımından bitkilere uygulanabilir arıtma çamurlarındaki patojen mikroorganizmalar, bu zengin organik madde kaynağının kullanımında sınırlayıcı unsur olarak değerlendirilmektedir [11,12]. Göreceli olarak yüksek düzeylerde patojen mikroorganizma içeren arıtma çamurlarının büyük miktarlardaki üretimi de bu materyalin yeni ekolojik sorunlara yol açmaksızın güvenli bertarafi için çözüm gereksinimini artırmaktadır. $\mathrm{Bu}$ açıdan arıtma çamurlarının en ekonomik bertaraf yöntemi olarak görülen süs bitkisi yetiştiriciliğinde kullanımının getireceği olumlu ve olumsuz etkilerin halk sağlığ açısından iyi belirlenmesi gerekmektedir.

$\mathrm{Bu}$ açıdan USEPA yönetmeliğinde arıtma çamurları, içerdikleri patojenlere bağlı olarak A sınıfı (doğrudan temas için güvenli) ve B sınıfı (arazide ve bitkisel üretimde kısıtlı kullanım) olmak üzere iki gruba ayrılmıştır. Buna göre A sınıfı arıtma çamurlarında $<1000$ EMS fekal koliform/1 g KM veya <3 EMS Salmonella/4 g KM seviyelerinde bakteri varlığına izin verilmektedir. B sınıfı arıtma çamurlarında ise fekal koliform sayısının geometrik ortalamasının 2.000.000 EMS /gr KM'den daha az olması istenmektedir [10].

Normal koşullarda $10^{5}$ ila $10^{7}$ EMS/gram (kuru ağırlık) fekal mikroorganizma içeren arıtma çamurunun araziye uygulandığında zamana ve bölgesel iklim koşullarına bağlı olarak içerdiği fekal indikatör mikroorganizmaların azaldığı ve güvenli sınırlara çekildiği yapılan çalışmalarla kanıtlanmıştır $[13,14]$. Özellikle yaz aylarında patojen mikroorganizmaların yaşama sürelerinin 1 ayı geçmediği, solar etki ile giderildiği tespit edilmiştir [12]. Bu çalışmada da, evsel nitelikli arıtma çamurlarının nihai bertaraf olarak süs bitkilerinde gübre amaçlı yetiştirme ortamı olarak değerlendirilmesi hedeflenerek mikrobiyal açıdan risk değerlendirmesi gerçekleştirilmiş, fekal orjinli bakteri popülasyonunun zamana bağlı değişimi incelenmiştir.

\section{MATERYAL VE METOT}

Çalışmada kullanılan evsel nitelikli arıtma çamuru, Adapazarı Büyükşehir Belediyesi'ne ait Karaman Evsel Atıksu Arıtma Tesisi'nden temin edilmiştir. Sistem arıtma tipi açısından uzun havalandırmalı aktif çamur sistemi olduğundan arıtımdan çıkan çamur USEPA'ya göre B sınıfi kategorisindedir. Arıtma çamuru tarımsal amaçlı bertarafta risk oluşturmayacak şekilde limit değerleri sağlamasının yanı sıra içerdiği ağır metal seviyeleri bakımından da tarımsal arazide uygulanmasında bir sakınca bulunmamaktadır. Çamur yoğunlaştırma prosesinden sonra belt filtreden çıkan yaklaşık \%20 kuru maddeye sahip ham çamur kekleri deneylerde kullanılmıştır. Karışımlarda, toprak ana bileşen, arıtma çamuru gübre sağlayıcı olarak düşünülerek hazırlanan yetiştirme ortamlarında toprağa hacimsel olarak (v/v) $\% 25$ ve $\% 50$ oranında arıtma çamuru ilave edilmiş ve denemeler 3 tekerrürlü olarak gerçekleştirilmiştir. Malzemeler hava kuru olarak karıştırılmıştır. Çamur ilave edilmemiş toprak uygulaması kontrol olarak alınmıştır.

Çalışmada bitkisel materyal olarak bölgede en çok rastlanan iç mekân süs bitkilerinden Yucca massengena, Areca lutescens, Chlorophytum comosum, Ficus elastica, Dieffenbachia maculata, Croton petra ve Sansevieria trifasciata kullanılmıştır. Bitkiler 4,5 litrelik saksılara aktarılmış ve iç ortamda tutulmuştur. Bitkilere ek gübreleme yapılmamış sadece kontrollü sulama gerçekleştirilmiştir. Yetiştirme ortamlarından alınan numunelerde, fekal koliform (termotolerant koliform) ve Escherichia coli (E. coli) tespiti 1,5 ay (6 hafta) boyunca haftalık olarak gerçekleştirilmiş, ilk numune alımı bitkilerin hazırlanan yetiştirme ortamlarına ekimlerinden 2 hafta sonra alınmıştır. Mikrobiyolojik analiz amaciyla alınan numuneler zaman kaybedilmeden işleme tabi tutulmuştur. Kimyasal ve fizikokimyasal analizler için alınan numuneler ise ilk olarak 48 saat $70{ }^{\circ} \mathrm{C}$ 'de kurutulduktan sonra porselen havanda ögütülen kuru numuneler $2 \mathrm{~mm}$ gözenekli elekten geçirilmiş ve elekten geçen kısım analizlerinde kullanılmıştır [15]. 
Denemede kullanılan arıtma çamurunun kimyasal ve fizikokimyasal özellikleri Çizelge 1 'de yer almaktadır. $\mathrm{pH}, 1: 5(\mathrm{w} / \mathrm{v})$ metoduna göre $\mathrm{pH}$ metre ile ölçülmüştür $[15,16]$. EC, 1:5 (w/v) metoduna uygun olarak sicaklık dikkate alınarak EC elektrotu ile tespit edilmiştir [15]. Organik madde muhtevas1; Walkley-Black metoduna göre \% organik maddesinin tespiti ve firın kuru ağırlık ilkesine göre (LOI) \% olarak hesaplanması şeklinde iki farklı metot uygulanarak saptanmıştır [15-17]. Toplam azot içeriği, bileşikler içindeki azotun derişik sülfürik asit ile amonyağa dönüştürülmesi ve amonyağın ortam içinde amonyum sülfat halinde tutulması prensibine dayanan Kjeldahl metodu ile belirlenmiş ve \% olarak ifade edilmiştir [15,18]. Fosfor içeriği, Bingham metoduna (suda çözünür $\mathrm{P}$ metodu) uygun olarak spektrofotometrik olarak tespit edilmiştir [19]. Potasyum içeriği, ICP (Perkin Emler, Optima 2100 DV) plazma yayım spektroskopisi ile tespit edilmiştir [16].

Çizelge 1. Deneylerde kullanılan arıtma çamurunun kimyasal ve fizikokimyasal özellikleri

\begin{tabular}{|l|c|}
\hline Parametreler & Ortalama \\
\hline $\mathrm{pH}$ & 7,6 \\
\hline İletkenlik $\left.(\mathrm{mS} \mathrm{cm})^{-1}\right)$ & 1,09 \\
\hline Organik madde $(\%)$ & 54,6 \\
\hline Kjeldahl azotu (\%) & 3,34 \\
\hline Fosfor $(\%)$ & 3,15 \\
\hline Potasyum (\%) & 0,12 \\
\hline $\mathrm{Cd}\left(\mathrm{mg} \mathrm{kg}^{-1}\right)$ & 3,4 \\
\hline $\mathrm{Cr}\left(\mathrm{mg} \mathrm{kg}^{-1}\right)$ & 243 \\
\hline $\mathrm{Cu}\left(\mathrm{mg} \mathrm{kg}^{-1}\right)$ & 19 \\
\hline $\mathrm{Ni}\left(\mathrm{mg} \mathrm{kg}^{-1}\right)$ & 79 \\
\hline $\mathrm{Pb}\left(\mathrm{mg} \mathrm{kg}^{-1}\right)$ & 34 \\
\hline $\mathrm{Zn}\left(\mathrm{mg} \mathrm{kg}^{-1}\right)$ & 1435 \\
\hline
\end{tabular}

Arıtma çamurundaki toplam ağır metal konsantrasyonlarının tespiti için, $250 \mathrm{mg}$ numune

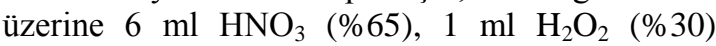
eklenerek mikrodalga firınında (Sorisole-Bg Italy)) 10 dakika $170{ }^{\circ} \mathrm{C}, 15$ dakika $200{ }^{\circ} \mathrm{C}, 10$ dakika $100{ }^{\circ} \mathrm{C}$ ve 10 dakika $100{ }^{\circ} \mathrm{C}$ olmak üzere toplam 45 dakika yakılmıştır. Numuneler soğutulduktan sonra ultra saf su ile $25 \mathrm{ml}$ 'ye tamamlanmış ve ağır metal absorbanslar1 ICP-OES (Spectro Arcos,
Kleve-Germany) spektroskopisinde ölçülmüştür [15].

Mikrobiyolojik analizler, hazır besiyerleri kullanılarak gerçekleştirilmiş, alınan örnekler yeterli seyreltmelerin $\left(\times 10^{2}\right)$ yapılmasının ardından aranan mikroorganizma türüne göre seçici bir besiyeri üzerine yerleştirilmiştir. $35{ }^{\circ} \mathrm{C}$ ve $41{ }^{\circ} \mathrm{C}$ 'lerde 24 saatlik inkübasyonun ardından besiyeri üzerindeki kareler yardımı ile sayım yapılmış, fekal koliform (termotolerant koliform) ve $E$. coli miktarları CFU/1 g (kuru madde) olarak tespit edilmiştir [20,21].

\section{1. İstatistiksel Analiz}

Uygulama boyunca her bir patojen mikroorganizmanın inaktivasyon oranı $\log$ N/No olarak hesaplanmıştır. Burada $\mathrm{t}=0$ anında yaşayan mikroorganizma konsantrasyonu No ve $t$ anındaki konsantrasyonu ise $\mathrm{N}$ olarak tanımlanmaktadır. Çalışmada en uygun mikrobiyal inaktivasyon model tipini belirlemek için GInaFiT inaktivasyon model oluşturma programı kullanılmıştır. E.coli ve termotolerant koliform için log-lineer regresyon gerçekleşen inaktivasyon denklemi en uygun inaktivasyon modeli olarak seçilmiştir. En uygun inaktivasyon eğrilerini belirlemede hata kareler ortalaması (RMSE) baz alınmıştır. İnaktivasyon hızı (kmax) değerleri GInaFiT programından elde edilen en uygun modele ait değerlerdir.

Bitki farklılığına bağlı olarak patojen giderim etkinliği ANOVA analizi ile belirlenmiştir. Bakteri sayıları istatistiki analize tabi tutulmadan önce normallik ve homojenliği sağlamak için $\mathrm{Xi}=\log (n i+1)$ formülü ile logaritmik tabana dönüştürülmüştür. Her bir bitki ve sürede tespit edilen ortalama değerler asgari önemli fark (LSD) testi ile belirlenmiştir $(p<0,05)$.

\section{BULGULAR VE TARTIŞMA}

Deneylerde kullanılan arıtma çamurunun başlangıç termotolerant koliform popülasyonu $25 \times 10^{5} \mathrm{CFU} / \mathrm{g}$ $\mathrm{KM}$, E. coli say1s1 ise $15 \times 10^{5} \mathrm{CFU} / \mathrm{g} \mathrm{KM}$ olarak tespit edilmiştir. Bitkiler temin edildiklerinde mevcut yetiştirme ortamları olan torfun 
termotolerant popülasyonu ise $2 \times 10^{2} \mathrm{CFU} / \mathrm{g} \mathrm{KM}$ iken $E$. coli'ye rastlanmamıştır.

7 farklı bitki çeşidi için elde edilen inaktivasyon kinetiği, GInaFiT inaktivasyon model seçimi için geliştirilmiş araç çubuğu kullanılarak belirlenmiştir. E.coli ve termotolerant koliform için inaktivasyon kinetiğini belirleyen model her bitki ve çamur ilave oranı için log-lineer model olarak bulunmuştur. (1) nolu inaktivasyon model denklemi en uygun model olarak seçilmiştir.

$N=N_{0} * e^{(-k \max * t)}$

Çizelge 2. $\% 25$ arıtma çamuru ilavesinde $E$. coli'nin maksimum inaktivasyon hızı, RMSE değerleri ve giderim verimleri

\begin{tabular}{|l|c|c|c|}
\hline Bitki çeşidi & $\mathbf{k}_{\mathbf{m a x}}$ & RMSE & $\begin{array}{c}\text { Verim } \\
(\%)\end{array}$ \\
\hline Yucca massengena & 2,29 & 2,423 & 80 \\
\hline Areca lutescens & 2,04 & 2,744 & 80 \\
\hline Chlorophytum comosum & 1,41 & 1,773 & 88 \\
\hline Ficus elastica & 1,71 & 2,129 & 93 \\
\hline Dieffenbachia maculata & 1,49 & 1,385 & 79 \\
\hline Croton petra & 2,03 & 2,05 & 91 \\
\hline Sansevieria trifasciata & 1,26 & 1,368 & 95 \\
\hline
\end{tabular}

$\mathrm{Bu}$ denkleme göre \%25 arıtma çamuru ilavesinde tüm bitkilerdeki $E$. coli giderimi benzerlik göstermiştir. \%25 arıtma çamuru ilavesinde $E$. coli ve termotolerant koliformların farklı süs bitkilerindeki inaktivasyonları Şekil 1'de verilmiştir. \%25 arıtma çamuru uygulamasında, farklı bitki çeşitlerinin zamana bağlı $E$. coli maksimum inaktivasyon hızları Çizelge 2'de verilmiştir. En yüksek giderim verimi (\%95) Sansevieria trifasciata bitkisinde tespit edilmiş, deneyin başlangıcında $20 \log _{10} \mathrm{CFU} / \mathrm{g}$ KM olarak ölçülen $E$. coli sayısı 6 haftalık deney süresinin sonunda $1 \log _{10} \mathrm{CFU} / \mathrm{g} \mathrm{KM}$ 'ye düşmüştür (Çizelge 2, Şekil 1). Bu bitkiyi takiben en yüksek giderim verimi (\%93) Ficus elastica bitkisinde tespit edilmiş, E. coli popülasyonu $28 \log _{10} \mathrm{CFU} / \mathrm{g}$ KM'den $2 \log _{10} \mathrm{CFU} / \mathrm{g}$ KM'ye düşmüștür. Croton petra bitkisi de yüksek $E$. coli giderim verimi (\%91) sergilemiş deney sürecinde $E$. coli popülasyonu $32 \log _{10} \mathrm{CFU} / \mathrm{g}$ KM'den $3 \log _{10}$ CFU/g KM'ye azalmıştır (Şekil 1). Tüm bitkiler genel olarak incelendiğinde zamana bağlı en yüksek $E$. coli inaktivasyonu 5 . haftada belirlenmiş, bu dönemde $E$. coli popülasyonunda en yüksek inaktivasyonlar elde edilmiştir (\%44-71). Deneyin devam eden günlerinde ise giderim verimi azalmıştır (\%20-50) (Şekil 1).

Çalışmada maksimum inaktivasyon hızı 2,29 ile Yucca massengena bitkisinde tespit edilmiştir. Bitki çeşitlerine bağlı olarak maksimum inaktivasyon hızları arasındaki ilişki göz önüne alındığında, istatistiksel olarak Areca lutescens ve Croton petra'daki kmax değerleri arasında benzerlik tespit edilmiştir. Elde edilen sonuçlar doğrultusunda çeşitli bitki profillerinde belirlenen E. coli sayısı zamana bağlı olarak hızlı bir azalış göstermiştir. Lineer regresyon analizlerinde de $E$. coli'nin logaritmik sayısında bitki çeşidi ve bekleme süresi ile ilişkili olarak büyük bir azalma olduğu gözlenmiştir.

Çizelge 3. $\% 50$ arıtma çamuru ilavesinde $E$. coli'nin maksimum inaktivasyon hızı, RMSE değerleri ve giderim verimleri

\begin{tabular}{|l|c|c|c|}
\hline Bitki çeşidi & $\mathbf{k}_{\mathbf{m a x}}$ & RMSE & $\begin{array}{c}\text { Verim } \\
(\mathbf{\%})\end{array}$ \\
\hline Yucca massengena & 2,85 & 0,905 & 47 \\
\hline Areca lutescens & 2,15 & 1,555 & 38 \\
\hline Chlorophytum comosum & 1,75 & 2,697 & 47 \\
\hline Ficus elastica & 2,06 & 1,555 & 50 \\
\hline Dieffenbachia maculata & 1,80 & 1,708 & 46 \\
\hline Croton petra & 2,35 & 1,902 & 49 \\
\hline Sansevieria trifasciata & 1,63 & 1,348 & 56 \\
\hline
\end{tabular}

\%50 arıtma çamuru uygulamasında, farklı bitki çeşitlerinin zamana bağlı $E$. coli maksimum inaktivasyon hızları Çizelge 3'de verilmiştir. \%50 arıtma çamuru ilavesinde $E$. coli ve termotolerant koliformların farklı süs bitkilerindeki inaktivasyonları Şekil 2'de verilmiştir. \%50 arıtma çamuru ilavesinde en yüksek giderim verimi (\%56) Sansevieria trifasciata bitkisinde olmuş, deneyin başlangıcında $45 \log _{10} \mathrm{CFU} / \mathrm{g}$ KM olarak ölçülen mikroorganizma sayısı deney süresinin sonunda $20 \log _{10} \mathrm{CFU} / \mathrm{g}$ KM'ye düşmüştür. Bu bitkiyi takiben en yüksek inaktivasyon verimleri sırasıyla Ficus elastica (\%50) ve Croton petra (\%49) bitkilerinde saptanmıştır. Chlorophytum comosum ve Yucca massengena bitkilerinde ise aynı giderim verimleri tespit edilmiştir (\%47) (Çizelge 3, Şekil 2). 
Bitkiler genel olarak incelendiğinde zamana bağlı en yüksek $E$. coli inaktivasyonu bitkiden bitkiye farklılık göstermiştir. Çalışmada maksimum inaktivasyon hızı 2,85 ile Yucca massengena bitkisinde tespit edilmiştir. Elde edilen sonuçlar doğrultusunda bitki çeşitlerinde belirlenen $E$. coli sayısı zamana bağlı olarak yavaş bir azalış göstermiş, giderim verimleri çok yüksek tespit edilmemiştir (\%38-56) (Şekil 2). Lineer regresyon analizlerinde de E. coli'nin logaritmik sayısında, bitki çeşidi ve uygulama süresi ile ilişkili olarak yavaş bir azalma olduğu gözlenmiştir.

Çizelge 4. $\% 25$ arıtma çamuru ilavesinde termotolerant koliformun maksimum inaktivasyon hızı, RMSE değerleri ve giderim verimleri

\begin{tabular}{|l|c|c|c|}
\hline Bitki çeşidi & $\mathbf{k}_{\mathbf{m a x}}$ & RMSE & $\begin{array}{c}\text { Verim } \\
(\mathbf{\%})\end{array}$ \\
\hline Yucca massengena & 7,73 & 9,211 & 89 \\
\hline Areca lutescens & 6,55 & 6,312 & 91 \\
\hline Chlorophytum comosum & 4,61 & 5,601 & 92 \\
\hline Ficus elastica & 4,57 & 3,643 & 90 \\
\hline Dieffenbachia maculata & 5,16 & 2,403 & 90 \\
\hline Croton petra & 6,80 & 7,367 & 90 \\
\hline Sansevieria trifasciata & 3,55 & 2,129 & 93 \\
\hline
\end{tabular}

\%25 arıtma çamuru ilavesinde en yüksek giderim verimi (\%93) E. coli ile benzer şekilde Sansevieria trifasciata bitkisinde tespit edilmiş, deneyin başlangıcında $60 \log _{10} \mathrm{CFU} / \mathrm{g} \mathrm{KM}$ olarak ölçülen mikroorganizma sayısı 6 haftalık deney süresinin sonunda $4 \log _{10} \mathrm{CFU} / \mathrm{g}$ KM'ye düşmüştür. $\mathrm{Bu}$ bitkiyi takiben en yüksek inaktivasyon verimleri sirasiyla Chlorophytum comosum (\%92) ve Areca lutescens (\%91) bitkilerinde saptanmıştır. Ficus elastica, Dieffenbachia maculata ve Croton petra bitkilerinde ise benzer giderim verimleri tespit edilmiştir $(\% 90)$. Tüm bitkilerdeki termotolerant koliform giderimi ise benzerlik göstermiştir (Çizelge 4, Şekil 1).

Bitkiler genel olarak incelendiğinde zamana bağlı en yüksek termotolerant koliform inaktivasyonu $E$. coli'den farklı olarak 6 . haftada belirlenmiş, bu dönemde tüm bitkilerde en yüksek inaktivasyonlar elde edilmiştir (\%44-71) (Şekil 1). E. coli popülasyonları için yeterli gelen 5 haftalık sürede termotolerant koliformların giderilmesi için yeterli gelmemiş, bu fekal mikroorganizmaların büyük oranda ( $>\% 90)$ inaktivasyonları için 6 hafta gerekli görülmüştür (Şekil 1). \%25 arıtma çamuru uygulamasında, farklı bitki çeşitlerinin zamana bağlı termotolerant koliform maksimum inaktivasyon hızları Çizelge 4'de verilmiştir. Çalışmada maksimum inaktivasyon hızı 7,73 ile Yucca massengena bitkisinde tespit edilmiştir.

Elde edilen sonuçlar doğrultusunda bitki çeşitlerinde belirlenen termotolerant koliform sayısı zamana bağlı olarak hızlı bir azalış göstermiştir. Lineer regresyon analizlerinde de termotolerant koliform'un logaritmik sayısında, bitki çeşidi ve uygulama süresi ile ilişkili olarak büyük bir azalma olduğu gözlenmiştir.

Çizelge 5. \%50 arıtma çamuru ilavesinde termotolerant koliformun maksimum inaktivasyon hızı, RMSE değerleri ve giderim verimleri

\begin{tabular}{|l|c|c|c|}
\hline Bitki çeșidi & $\mathbf{k}_{\max }$ & RMSE & $\begin{array}{c}\text { Verim } \\
(\mathbf{\%})\end{array}$ \\
\hline Yucca massengena & 4,81 & 10,284 & 29 \\
\hline Areca lutescens & 4,80 & 9,307 & 29 \\
\hline Chlorophytum comosum & 4,81 & 6,022 & 44 \\
\hline Ficus elastica & 3,42 & 2,702 & 30 \\
\hline Dieffenbachia maculata & 3,63 & 2,776 & 32 \\
\hline Croton petra & 4,97 & 5,364 & 32 \\
\hline Sansevieria trifasciata & 3,46 & 2,678 & 41 \\
\hline
\end{tabular}

\%50 arıtma çamuru uygulamasında, farklı bitki çeşitlerinin zamana bağlı termotolerant koliform maksimum inaktivasyon hızları Çizelge 5'de verilmiştir. \%50 arıtma çamuru ilavesinde en yüksek giderim verimi (\%44) Chlorophytum comosum bitkisinde olmuş, deneyin başlangıcında $157 \quad \log _{10} \quad \mathrm{CFU} / \mathrm{g} \quad \mathrm{KM}$ olarak ölçülen mikroorganizma sayısı deney süresinin sonunda 88 $\log _{10} \mathrm{CFU} / \mathrm{g}$ KM'ye düşmüştür. Bu bitkiyi takiben en yüksek inaktivasyon verimleri sirasıyla Sansevieria trifasciata (\%41) ve Croton petra (\%32) bitkilerinde saptanmıştır. Areca lutescens ve Yucca massengena bitkilerinde ise aynı giderim verimleri tespit edilmiştir (\%29) (Çizelge 5, Şekil 2). 
Bitkiler genel olarak incelendiğinde zamana bağlı en yüksek termotolerant koliform inaktivasyonu bitkiden bitkiye farklılık göstermiştir. Çalışmada maksimum inaktivasyon hizı 4,97 ile Croton petra bitkisinde tespit edilmiştir (Şekil 2). Elde edilen sonuçlar doğrultusunda bitki çeşitlerinde belirlenen termotolerant koliform sayısı zamana bağlı olarak yavaş bir azalış göstermiş, giderim verimleri çok yüksek tespit edilmemiştir (\%29-44) (Şekil 2). Lineer regresyon analizlerinde de termotolerant koliform'un logaritmik sayısında, bitki çeşidi ve uygulama süresi ile ilişkili olarak yavaş bir azalma olduğu gözlenmiştir.
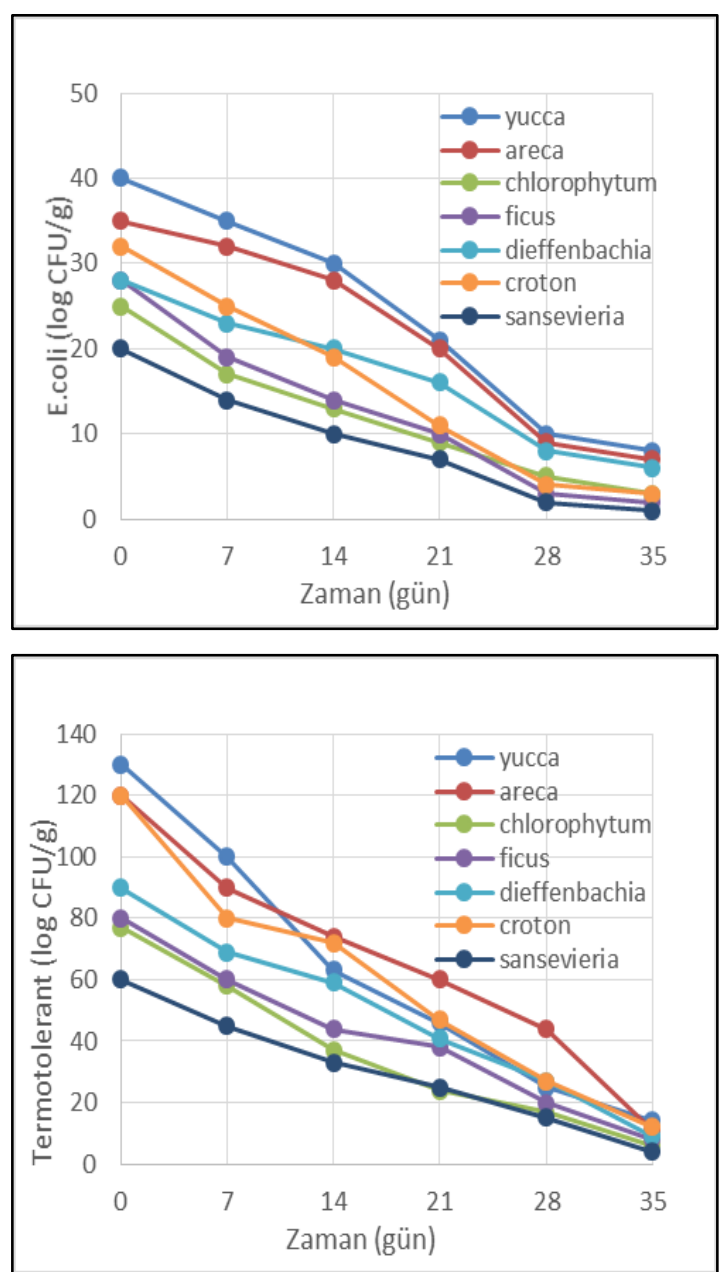

Şekil 1. \%25 arıtma çamuru ilavesinde E. coli ve termotolerant koliformların farklı süs bitkilerindeki inaktivasyonları
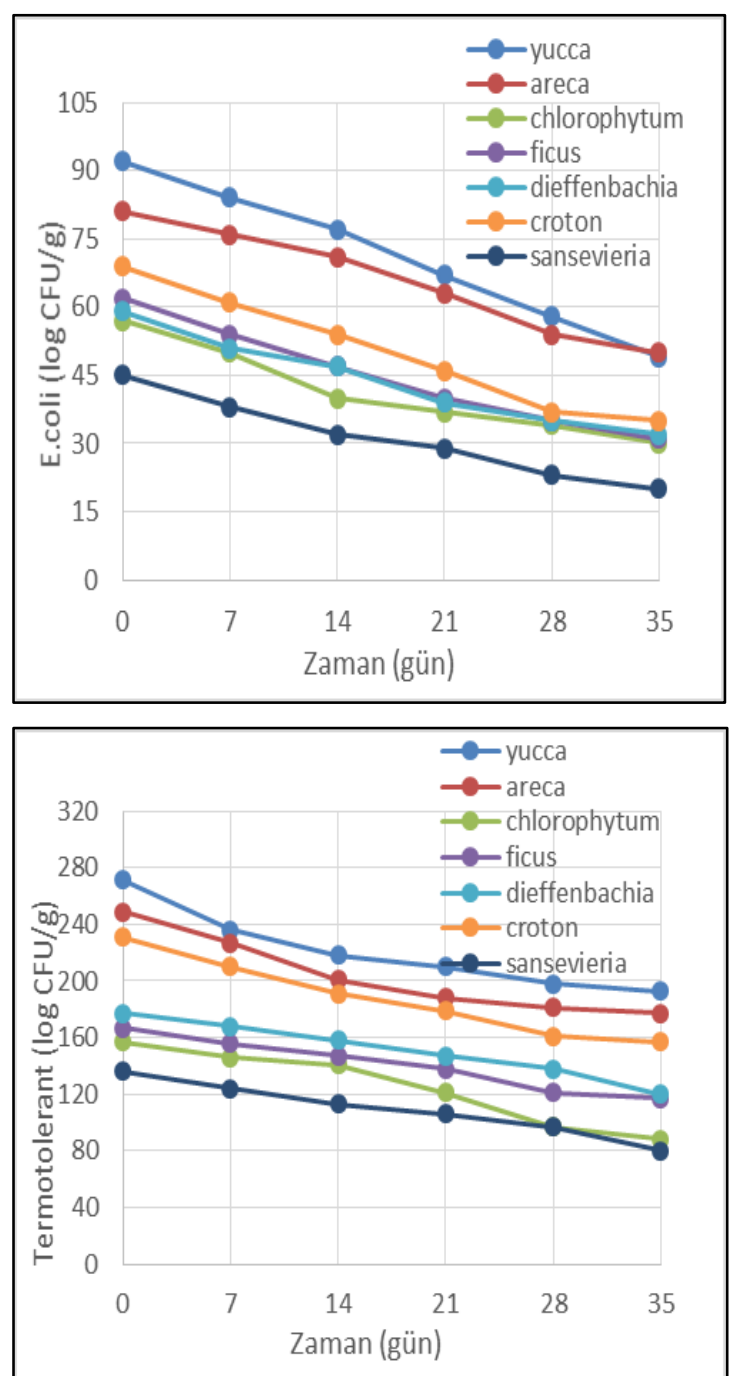

Şekil 2. \%50 arıtma çamuru ilavesinde $E$. coli ve termotolerant koliformların farklı süs bitkilerindeki inaktivasyonları

\section{SONUÇ VE ÖNERİLER}

Çalışmada başlıca indikatör mikroorganizmalardan E. coli ve termotolerant koliform'un süs bitkisi toprağına ilave edilerek bekleme süresine bağlı her bir bitki çeşidi için elde edilen inaktivasyon kinetikleri belirlenmiştir. İncelenen mikroorganizmaların popülasyonlarının sayılarındaki azalma zaman ile pozitif korelasyon gösterirken, bitkiden bitkiye çeşitlilik sergilemiştir. 
E. coli gideriminde çeşitli parametrelerin etkin olduğu aşikardır. $\mathrm{Bu}$ çalışmada zamana bağlı giderim verimliliği farklı süs bitkileri bazında ele alınmış olsa da sıcaklığın fekal indikatör mikroorganizma giderimi üzerindeki baskın etkisini destekleyecek çalış̧alarda gerçekleştirilmiş bilhassa topraktaki $\mathrm{CO}_{2}$ seviyesindeki artışların da patojen yıkım veriminde etkili olduğu ispatlanmıştır [22,23]. Deney sürecinde iç mekân sıcaklık değerlerinde çok büyük değişimler gerçekleşmemiş, ortam sıcaklığı sabit tutulmuştur $\left(2{ }^{\circ} \mathrm{C}\right)$. Buna bağlı olarak mikroorganizma gideriminin sicaklıktan ziyade bekleme süresi ve çamurda gerçekleşen biyokimyasal etkileşimler gibi diğer faktörlere bağlı olarak gerçekleştiği düşünülebilir. Anaerobik koşulların oluşması ile beraber ortamda oluşan $\mathrm{CO}_{2}$ ve mikrobiyal türler arasındaki rekabet patojen gideriminde etkilidir. Bunun yanı sıra bitkilerin köklerinden salgıladıkları organik asitler ile kök bölgesini asitlendirmeleri, patojen gideriminde önemli bir parametredir. Ancak termotolerant koliform sayısındaki bu düşük azalış, ortama adaptasyon gösteren fraksiyonunun varlığını devam ettirmesine bağlanmıştır. Sonuç olarak B sınıfı standartları sahip arıtma çamuru, A sınıfi özelliklere kavuşmuş, süs bitkisi toprağı kullanımına yönelik bir sakınca oluşturmamasının yanı sıra insan tüketimine yönelik ürünlerin yetiştirilmesinde de güvenle kullanılabileceği ispatlanmıştır.

\section{KAYNAKLAR}

1. Arıkan, O.A., Öztürk, İ., 2005. Arıtma Çamuru Kompostlaştııılmasında Organik Evsel Katı Atık İlavesinin Etkisi, İTÜ Dergisi/d, 4(1): 15-24.

2. Uzun, P., Bilgili, U., 2011. Arıtma Çamurlarının Tarımda Kullanılma Olanakları. U. Ü. Ziraat Fakültesi Dergisi, 25(2): 135-146.

3. Demirkan, Ç.G., Akat, H., Yokaş, İ., 2014. Atık Su Arıtma Çamurunun Clarkia amoena (yer açelyası) Türünde Bitki Gelişimi ve Çiçeklenme Üzerine Etkisi, U.Ü. Ziraat Fakültesi Dergisi, 28(2): 49-57.
4. Bozdoğan, E., Çetinkale, G., Söğüt, Z., 2009. Atık Su Arıtma Çamurlarının Yeniden Kullanımları, Ulusal Katı Atık Yönetimi Kongresi-UKAY, 334-342, Eskişehir.

5. Akat, H., Demirkan, Ç.G., Yokaş, İ., 2013. Atık Çamurun 'Matthiola incana' Yetiştiriciliğinde Bitki Gelişimi ve Kalite Üzerine Etkisi, 5. Ulusal Katı Atık Yönetimi Kongresi, 508-520, Kocaeli.

6. Demirkan, Ç.G., Akat, H., Yokaş, İ., 2013. Atık Çamurun Kapak Malzemesi Olarak Kullanımının Bazı Çim Türlerine Etkisi, V. Süs Bitkileri Kongresi, Yalova.

7. Akat, H., Demirkan, Ç.G., Akat, Ö., Yokaş, İ., 2015. Limonium sinuatum Yetiştiriciliğinde Farklı Ortamlara İlave Edilen Atık Su Arıtma Çamurunun Süs Bitkisi Yetiştirme Materyali Karışımı Olarak Kullanımı, Tekirdağ Ziraat Fakültesi Dergisi, 12(1): 81-90.

8. Yaman, K. ve Olhan, E., 2011. Arıtma Çamuru Kullanımının Buğdayın Verim, Fiziki Girdi ve Maliyetleri Üzerindeki Etkisi, Tarım Bilimleri Dergisi, 17: 157-166.

9. Önal, K.M., Topçuoğlu, B., Arı, N., 2003. Toprağa Uygulanan Kentsel Arıtma Çamurunun Domates Bitkisine Etkisi, II. Gelişme ve Meyve Özellikleri ile Meyvede Mineral İçerikleri, Akdeniz Üniversitesi Ziraat Fakültesi Dergisi, 16(1): 97-106.

10. Dede, G., 2016. Biyokatıların Mera Islahında Değerlendirilmesi-Risk Potansiyeli, Karaelmas Fen ve Mühendislik Dergisi, 6(1): 168-173.

11. Cabaret, J., Geerts, S., Madeline, M., Ballandonne, C., Barbier, D., 2002. The Use of Urban Sewage Sludge on Pastures: The Cysticercosis Threat, Vet. Res., 33: 575-597.

12. Serrao, M.G., Domingues, H., Fernandes, M., Martins, J., Pires, F., Saraiva, I., Fareleira, P., Matos, N., Ferreira, E., Campos, A.M., 2009. Contribution to the Improvement of Degraded Soils Under Pastures Through Sewage Sludge Application, Without Environmental Risks, Rev. Cien. Agric., 32: 258-272.

13. Serrao, M.G., Martins, J.C., Fareleira, P., Branco M.A.C., Varela, A., Domingues, H., Fernandes, M., Pires, F., Guerreiro, A., Ramos, J., 2010. Impact of Sewage Sludge and Mineral Fertilizers Application in Soils Under Pasture 
from the Alentejo Region, Rev. Cien. Agric., 33: 139-149.

14. Famens, G.J., Waldron, A.M., 2008. Salmonella Uptake in Sheep Exposed to Pastures After Biosolids Application to Agricultural Land, Aust. J. Soil Res., 46: 302-308.

15. Kalra, Y.P., Maynard, D.G., 1991. Methods Manual for Forest Soil and Plant Analysis, Forestry Canada, Northwest Region, Northern forest Centre, Edmonton, Alberta, Information Report NOR-X319.

16. Ryan, J., Estefan, G., Rashid, A., 2001. Soil and Plant Analysis Laboratory Manual. Second Edition. Jointly Published by the International Center for Agricultural Research in the Dry Areas (ICARDA) and the National Agricultural Research Center (NARC), Available from ICARDA, Aleppo, Syria.

17. Schulte, E.E., 2009. Recommended Soil Organic Matter Tests, Chapter 8. University of Delaware Cooperative Extension, College of Agriculture \& Natural Resources.

18. Craft, C.B., Seneca, E.D., Broome, S.W., 1991. Loss on Ignition and Kjeldahl Digestion for Estimating Organic Carbon and Total Nitrogen in Estuarine Marsh Soils: Calibration with Dry Combustion, Estuaries, Vol. 14, No. 2, 75-179.

19. Pierzynski, G.M., 2000. Methods of Phosphorus Analysis for Soils, Sediments, Residuals, and Waters, Southern Cooperative Series Bulletin, No. 396, June.

20. ISO 9308-1, 2014. Water quality - Detection and Enumeration of Escherichia Coli and Coliform Bacteria, Part- 1: Membran Filtration Method.

21. ISO 16649-2, 2001. Microbiology of Food and Animal Feeding Stuffs-Horizontal Method for the Enumeration of Beta-GlucuronidasePositive E. coli. Part 2: Colony-Count Technique at 44 Degrees C Using 5-Bromo-4Chloro-3-Indolyl Beta-D-Glucuronide.

22. Emmoth, E., Dergel, I., McNeilly, F., Allan, G.M., Albihn, A., Klingeborn, B., 2004. Heat Inactivation of Porcine Circovirustype $2,11^{\text {th }}$ International Conference Recycling of Agricultural, Municipal and Industrial Residues in Agriculture, Murcia, Spain.
23. Jones, K., 2001. Campylobacter in Water, Sewage and the Environment, J Appl Microbiol., 90: 68-79. 
